P-ISSN :2655-9811, E-ISSN:2656-1964

J. Feasible., Vol. 3, No.1, Februari $2021(55-61)$

(c) 2019 Pusat InkubasiBisnis dan Kew irausahaan

Universitas Pamulang (PINBIKUNPAM)
JURNAL ILMIAH

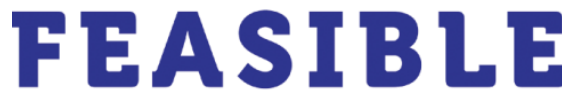

BISNIS, KEWIRAUSAHAAN \& KOPERASI

\title{
Pengaruh Kualitas Produk Dan Kualitas Pelayanan Terhadap Kepuasan Pelanggan Pada Rich Perfumery ITC Kuningan Jakarta Selatan
}

\author{
Yumelin Adelina Sinaga ${ }^{*}$, Feb Amni Hayati², Uswatun Chasanah ${ }^{3}$ \\ 1,3Fakultas Ekonomi Universitas Pamulang; dosen01657@unpam.ac.id* \\ 2Fakultas Ekonomi Universitas Pamulang; dosen02021@unpam.ac.id
}

\begin{abstract}
Abstrak
Penelitian ini bertujuan untuk mengetahui pengaruh Kualitas Produk dan Kualitas Pelayanan terhadap Kepuasan Pelanggan pada Rich Perfumery ITC Kuningan. Penelitian yang dilakukan dalam penulisan ini bersifat deskriptif kuantitatif dengan pengujian hipotesis yang diproses menggunakan sistem aplikasi SPSS ver.23. Populasi yang didapat dari data penelitian konsumen yang berbelanja di Rich Perfumery ITC Kuningantidakdiketahuijumlahnya hingga menggunakan teknik sampel jenuh dengan jumlah8oresponden. Metodeanalisis data yang digunakan adalah uji validitas, uji reliabilitas, koefisienkorelasi, koefisien determinasi, regresi linier sederhana,regresi linier berganda,uji asumsi klasik dan hipotesis. Terdapat pengaruh yang positif dan signifikan antara kualitas produk dan kualitaspelayanan terhadap kepuasan pelanggan pada Rich Perfumery ITC Kuningan. Hal inidibuktikan dengan uji regresi berganda $Y=1,301+0,525 X_{1}+0,437 X_{2}$, Korelasi product momentdengan hasil o,886 dan nilai $K D$ sebesar78,5\% sisanya 21,5\% dipengaruhi faktor lain yang tidakditeliti. Dan dari hasil uji hipotesis yang dihasilkan sebesar $F_{\text {hitung }} 140,656>$ dari $F_{\text {tabel }} 3,12$.
\end{abstract}

Kata kunci: Kualitas Produk; Kualitas Pelayanan; Kepuasan Pelanggan

\begin{abstract}
This study aims to determine the effect of Product Quality and Service Quality on Customer Satisfaction at Rich Perfumery ITC Kuningan.Research conducted in this writing is quantitive descriptive by testing hypothesis which are processed using the SPSS version 23 application system.The population obtained from research data of consumers who shop at Rich Perfumery ITC Kuningan is unknown until it uses a saturated sample technique with a total of 80 respondents.The data analysis method used is validity test,reliability test,corelation coefficient ,determination coefficient, simple linier regression,multiple linier regression, classical assumption test and hypothesis.There is a positive and significant influence between product quality and service quality on consumers satisfaction at Rich Perfumery ITC Kuningan.This is evidenced by the multiple regression test $Y=1.301+0.525 X_{1}+0.437 X_{2}$, the product moment correlation with the result of 0.886 and the KD value of $78.5 \%$ the remaining $21.5 \%$ is influenced by other factors not examined.

And from the result of the hypothesis test that results from $F_{\text {count }} 140.656>$ from $F_{\text {table }}$ of 3.12
\end{abstract}

Keywords : Product Quality; Service Quality; Consumer Satisfaction

*) Korespondensi penulis 


\section{PENDAHULUAN}

Perubahan ekonomi di era yang serba modern seperti saat ini, menjadikan tingkat persaingan bisinis meningkat yang membuat perusahaan berlomba-lomba untuk mempertahankan, memenangkan persaingan pasar serta memperluas eksistensinya. Kebutuhan dan keinginan konsumen tersebut selalu mengalami perubahan seiring dengan perkembangan zaman sehingga mempengaruhi system pola konsumsi masyarakat. Bidang usaha yang berkembang pesat pada saat ini salah satunya adalah dibidang wewangian. Industri wewangian disini didefinisikan sebagai industri yang menjual produk dan jasa pelayanan yang telah diberinilai tambah untuk memenuhi kebutuhan pribadi, keluarga, kelompok, atau pemakai akhir. Salah satunya adalah refill perfume store itu adalah Rich Perfumery yang bertempat di ITC Kuningan Jalan Professor Doktor Satrio no.18, Kuningan, Jakarta Selatan yang dubuka pada awal Februari 2011. Perusahaan yang ingin berkembang dan mendapatkan keunggulan kompetitif harus memberikan produk berupa barang atau jasa berkualitas dengan harga yang terjangkau, penyerahan yang lebih cepat, dan pelayanan yang baik kepada para pelanggan pada sebuah perusahaan dibidang pelayanan, kualitas pelayanan sangat penting dikelola perusahaan dengan baik

\section{Tabel 1. Data Pelayanan}

Pelanggan Rich Perfumery 2020

\begin{tabular}{|c|l|l|l|c|}
\hline No & $\begin{array}{l}\text { Dimensi } \\
\text { Pelayanan }\end{array}$ & $\begin{array}{c}\text { Standar } \\
\text { Pelayanan }\end{array}$ & Kondisi Riil & Ket. \\
\hline 1 & $\begin{array}{l}\text { Daya } \\
\text { Tanggap } \\
\text { (responsive } \\
\text { ness) }\end{array}$ & $\begin{array}{l}\text { Cepat } \\
\text { dan } \\
\text { tanggap }\end{array}$ & $\begin{array}{l}\text { Cepat dan } \\
\text { tanggap } \\
\text { melayani } \\
\text { pelanggan }\end{array}$ & Sesuai \\
& $\begin{array}{l}\text { Pelayanan } \\
\text { yang } \\
\text { diberikan }\end{array}$ & & & \\
& & & \\
& pada & & \\
pelanggan & & & \\
\hline 2 & $\begin{array}{l}\text { Keandalan } \\
\text { (Reliablity) }\end{array}$ & Akurat dan & Tidak & Tidak \\
& terpercaya & sesuai & sesuai \\
& dengan & \\
& Rich & & keinginan & \\
& Perfumery & & pelanggan & \\
sesuai yang & & & \\
\hline
\end{tabular}

\begin{tabular}{|c|c|c|c|c|}
\hline & dijanjikan & & & \\
\hline 3 & $\begin{array}{l}\text { Bukti Fisik } \\
\text { (Tangibles) } \\
\text { Kondisi } \\
\text { tempat } \\
\text { penjualan }\end{array}$ & $\begin{array}{l}\text { Nyaman } \\
\text { dan bersih }\end{array}$ & $\begin{array}{l}\text { Kotor dan } \\
\text { tidak rapi }\end{array}$ & $\begin{array}{l}\text { Tidak } \\
\text { sesuai }\end{array}$ \\
\hline 4 & $\begin{array}{l}\text { Jaminan } \\
\text { (Assurance) } \\
\text { Memberikan } \\
\text { pelayanan } \\
\text { yang sopan }\end{array}$ & $\begin{array}{l}\text { Ramah dan } \\
\text { Sopan }\end{array}$ & $\begin{array}{l}\text { Kurang } \\
\text { ramah }\end{array}$ & $\begin{array}{l}\text { Tidak } \\
\text { Sesuai }\end{array}$ \\
\hline 5 & $\begin{array}{l}\text { Empati } \\
\text { (Empathy) } \\
\text { Komunikasi } \\
\text { yang baik }\end{array}$ & $\begin{array}{l}\text { Mudah } \\
\text { dipahami }\end{array}$ & Informatif & Sesuai \\
\hline
\end{tabular}

Sumber :Prasurvey2020

Melihat data diatas, dapat diketahui bahwa keluhan pelayanan pelanggan pada Rich Perfumery selalu mengalami penurunan dalam melayani pelanggan yang ingin berbelanja dan ingin mengajukan komplain pada Rich Perfumery dan tidak melakukan standar pelayanan yang seharusnya dilakukan.

Tabel 2. Data Keluhan Pelanggan Rich Perfumery ITC Kuningan 2020

\begin{tabular}{|l|l|l|}
\hline No & \multicolumn{1}{|c|}{$\begin{array}{c}\text { Keluhan } \\
\text { Pelanggan }\end{array}$} & \multicolumn{1}{c|}{ Alasan } \\
\hline $\mathbf{1}$ & $\begin{array}{l}\text { Pegawai tidak tahu } \\
\text { informasi saat } \\
\text { ditanya tentang } \\
\text { parfum baru. }\end{array}$ & $\begin{array}{l}\text { Pegawai masih } \\
\text { belum mengetahui } \\
\text { pengetahuan } \\
\text { mengenai produk. }\end{array}$ \\
\hline $\mathbf{2}$ & $\begin{array}{l}\text { Keadaan toko } \\
\text { tidak tertata rapi } \\
\text { dan tidak bersih. }\end{array}$ & $\begin{array}{l}\text { Toko berdebu dan } \\
\text { berantakan. }\end{array}$ \\
\hline $\mathbf{3}$ & $\begin{array}{l}\text { Tidak dapat } \\
\text { tempat duduk saat } \\
\text { hendak membeli. }\end{array}$ & $\begin{array}{l}\text { Kurangnya tempat } \\
\text { duduk saat melayani. }\end{array}$ \\
\hline $\mathbf{4}$ & $\begin{array}{l}\text { Saat ditanya jutek } \\
\text { dan tidak langsung } \\
\text { merespon. }\end{array}$ & $\begin{array}{l}\text { Pegawai tidak ramah } \\
\text { dan judes. }\end{array}$ \\
\hline $\mathbf{5}$ & $\begin{array}{l}\text { Melayani tidak } \\
\text { fokus pada } \\
\text { pelanggan. }\end{array}$ & $\begin{array}{l}\text { Pegawai bercanda } \\
\text { saat melayani } \\
\text { pembeli. }\end{array}$ \\
\hline $\mathbf{6}$ & $\begin{array}{l}\text { Parfum } \\
\text { meninggalkan } \\
\text { bercak kuning } \\
\text { dipakaian putih } \\
\text { diPolo shirt dan } \\
\text { bahan satin juga } \\
\text { sutra. }\end{array}$ & $\begin{array}{l}\text { Menyemprot parfum } \\
\text { terlalu dekat dengan } \\
\text { pakaian. }\end{array}$ \\
\hline $\mathbf{7}$ & $\begin{array}{l}\text { Jika disemprot ke } \\
\text { belakang leher dan } \\
\text { tangan suka panas. }\end{array}$ & $\begin{array}{l}\text { Iritasi untuk kulit } \\
\text { yang sensitif. }\end{array}$ \\
\hline Sumber :Olahan Peneliti Juli 2020 \\
\hline
\end{tabular}

Berdasar hasil service after sales ini dapat dilihat hampir sebagian besar responden mengatakan bahwa faktorfaktor yang mepengaruhi kualitas pelayan- 
an adalah faktor keandalan, bukti langsung, dan jaminan daya tanggap. Banyak hal yang mempengaruhi kepuasan pelanggan, diantaranya adalah kualitas pelayanan dan kualitas produk. Tabel berikut ini adalah data jumlah pelanggan pada Rich Perfumery yaitu sebagai berikut:

Tabel 3. Data JumlahPelanggan Rich Perfumery ITC Kuningan 2020

\begin{tabular}{|c|c|}
\hline Tahun & $\begin{array}{c}\text { Informasi } \\
\text { Pelanggan }\end{array}$ \\
\hline 2017 & 789 \\
\hline 2018 & 697 \\
\hline 2019 & 673 \\
\hline Jumlah & $\mathbf{2 1 6 5}$ \\
\hline
\end{tabular}

Sumber : Rich Perfumery ITC Kuningan 2020

Berdasarkan tabel diatas terlihat jumlah keseluruhan pelanggan mengalami penurunan dari tahun 2017 sampai 2019 penurunan ini disebabkan karena banyakanya konsumen yang merasa kurang puas dengan produk dan pelayanan yang dihadirkan oleh Rich perfumery. Hal ini dibuktikan dengan tabel 1.3 dan 1.4 yang mengalami penurunan pada jumlah pembeli dan meningkatnya jumlah keluhan pada Rich Perfumery ITC Kuningan.

Penelitian ini untuk menganalisis pengaruh kualitas produk dan kualitas pelayanan terhadap kepuasan pelanggan, dengan melakukan penelitian yang berjudul "Pengaruh Kualitas Produk dan Kualitas Pelayanan terhadap Kepuasan Pelanggan pada Rich Perfumery ITC Kuningan Jakarta Selatan”.

\section{METODE}

Metode deskriptif kuantitatif digunakan untuk menjelaskan hasil kuesioner yang berisi variabel yang berkaitan dengan kualitas produk, kualitas layanan dan kepuasan pelanggan. Skala linkert digunakan untuk memberikan bobot kuesioner. Nilai 5 untuk bobot pernyataan yang sangat penting dan nilai 1 jika pernyataan kuesioner kurang penting. Uji Analisa yang digunakan meliputi uji asumsi klasik, uji hipotesis dan deteterminasi.

Penelitian dilakukan dilakukan pada di Rich Perfumery ITC Kuningan yang beralamat di ITC Kuningan Lantai 2 No.7-8 Jembatan I, Jalan Professor Doktor Satrio no.18, Kuningan, Karet, Jakarta Selatan, kontak : 085959182255. Dengan jumlah sampel yang dianalisis 80 responden pelanggan yang dipilih secara random (acak).

\section{HASIL dan PEMBAHASAN}

\section{Uji Asumsi Klasik}

Uji Normalitas, untuk menguji data apakah terdistribusi normal atau tidak normal.

Tabel 4. Uji Normalitas dengan Kolmogorov-Smirnov

\begin{tabular}{|l|r|r|r|} 
& \multicolumn{3}{|c|}{ Kolmogorov-Smirnova } \\
& Statistic & Df & \multicolumn{1}{c|}{ Sig. } \\
\hline Kepuasan & ,093 & 80 & ,087 \\
Pelanggan & & & \\
\hline
\end{tabular}

a. Lilliefors Significance Correction

Sumber : Hasil olah data SPSS 23 (2020)

Dari hasil dapat disimpulkan bahwa data terdistribusi normal, karena nilai signifikansi kepuasan pelanggan 0,087 > 0,05. Uji normalitas juga dapat dilakukan dengan melihat grafik P-Plot.

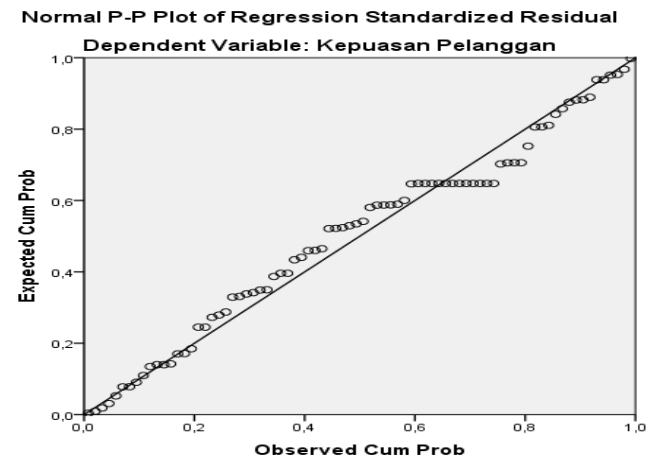

Gambar 2. Uji Normalitas Data P-P Plot

Hasil uji P-P plot terlihat titik-titik menyebar di sekitar garis diagonal dan penyebarannya mengikuti arah garis diagonal. Artinya data yang digunakan berdistribusi normal. 
Uji Multikolineritas, bertujuan untuk menguji apakah dalammodel regresi terdapat korelasi antar variabel bebas (independent.

\section{Tabel 5. Uji Multikolineritas}

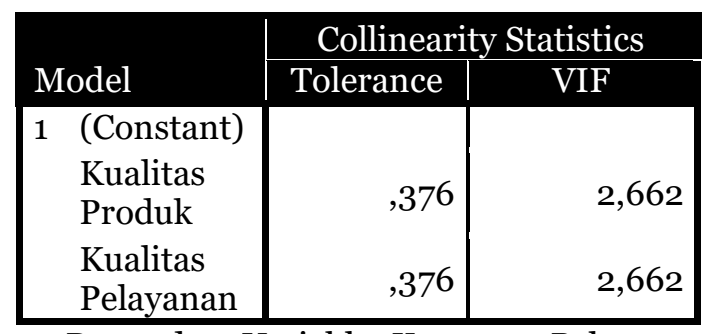

a. Dependent Variable: Kepuasan Pelanggan

Berdasarkan tabel tersebut maka dapat diketahui nilai tolerance $0,376>0,10$ dan Nilai VIF sebesar 2,662< 10 sehingga pada variabel bebas tidak terjadi gejala multikolinieritas.

Uji Heteroskedastisitas, bertujuan untuk mengetahui ada dan tidak adanya kesamaan deviasi standar nilai variabel dependen pada setiap variabel independen. Deteksi dengan melihat ada tidaknya pola tertentu pada grafik.

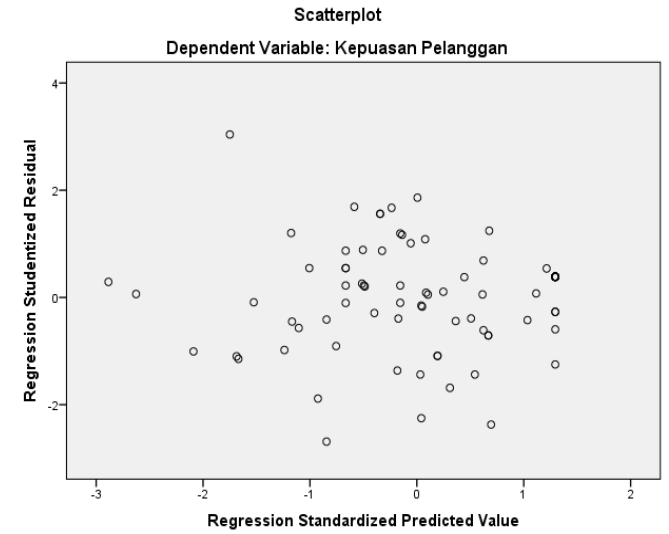

Gambar 3. Uji Heteroskedastisitas

Dari grafik dapat terlihat titik-titik yang menyebar secara acak, tidak membentuk suatu pola tertentu yang jelas, serta tersebar baik di atas maupun di bawah angka o (nol) pada sumbu Y, maka tidak terjadi heteroskedastisitas.

\section{Uji Regresi Linier Berganda}

\section{Tabel 6. Regresi Linier Berganda Coefficients $^{\text {a }}$}

\begin{tabular}{|c|c|c|c|c|c|c|}
\hline & & $\begin{array}{r}\text { Unstar } \\
\text { Coef }\end{array}$ & $\begin{array}{l}\text { ardized } \\
\text { ients }\end{array}$ & $\begin{array}{l}\text { Standardized } \\
\text { Coefficients }\end{array}$ & & \\
\hline & odel & B & $\begin{array}{c}\text { Std. } \\
\text { Error }\end{array}$ & Beta & $\mathrm{T}$ & Sig. \\
\hline 1 & (Constant) & 1.301 & 3,009 & & 432, & 667 \\
\hline & $\begin{array}{l}\text { Kualitas } \\
\text { Produk }\end{array}$ & .525 & .087. & 519 & 6,019 & , 000 \\
\hline & $\begin{array}{l}\text { Kualitas } \\
\text { Pelayanan }\end{array}$ & 473 & .098. & ,417 & 4,841 & ,000 \\
\hline
\end{tabular}

a. Dependent Variable: Kepuasan pelanggan

Berdasarkan tabel di atas, diperoleh persamaan regresi linier berganda $\mathbf{Y}=$ $\mathbf{1 , 3 0 1}+0,525 X_{1}+0,473 X_{2}$

Konstanta sebesar 1,301 artinya jika kualitas produk dan kualitas pelayanan, bernilai nol atau tidak meningkat maka kepuasan pelanggan akan tetap bernilai sebesar1,301.

Nilai regresi $0,525 \mathrm{X}_{1}$ (positif) artinya apabila variabel kualitas produk $\left(\mathrm{X}_{1}\right)$ meningkat sebesar 1 satuan dengan asumsi variabel kualitas pelayanan $\left(\mathrm{X}_{2}\right)$ dalam keadaan tetap, maka kepuasan pelanggan (Y) akan meningkat sebesar 0,525 satuan.

Nilai regresi $0,473 \mathrm{X}_{2}$ (positif) artinya apabila variabel kualitas pelayanan $\left(\mathrm{X}_{2}\right)$ meningkat sebesar 1 satuan, dengan asumsi variabel kualitas produk $\left(\mathrm{X}_{1}\right)$ tetap, maka kepuasan pelanggan (Y) akan meningkat sebesar 0,473 satuan.

\section{Uji Koefisien Determinasi}

Uji Koefisien determinasi digunakan untuk mengetahui seberapa besar kontribusi variabel independen mempengaruhi variabel dependen.

\section{Tabel 7. Hasil uji Koefisien Determinasi

\begin{tabular}{|c|c|c|c|c|}
\hline Model & $\mathrm{R}$ & $\begin{array}{c}\mathrm{R} \\
\text { Square }\end{array}$ & $\begin{array}{l}\text { Adjusted } \\
\text { R Square }\end{array}$ & $\begin{array}{l}\text { Std. Error of } \\
\text { the Estimate }\end{array}$ \\
\hline 1 & $.886^{\mathrm{a}}$ & .785 & .780 & .752 \\
\hline
\end{tabular}

Konstribusi variabel bebas terhadap variabel terikat ditunjukkan oleh nilai $R$ Square yaitu sebesar 0,785 yang artinya secara simultan variabel kualitas produk dan variabel kualitas pelayanan memberikan kontribusi atau pengaruh terhadap variabel kepuasan pelanggan sebesar $78,5 \%$, sedangkan sisanya sebesar $21,5 \%$ di 
pengaruhi oleh variabel lain yang tidak diteliti dalam penelitian ini.

\section{Uji Parsial (uji t)}

Uji parsial digunakan untuk menguji pengaruh setaiap variabel independent terhadap variabel dependennya. Berikut hasil uji parsial ditunjukkan pada tabel 8 .

\begin{tabular}{|c|c|c|c|c|c|c|}
\hline \multicolumn{7}{|c|}{$\begin{array}{c}\text { Tabel 8. Hasil uji parsial (uji t) } \\
\text { Coefficients }^{\mathrm{a}}\end{array}$} \\
\hline \multirow{2}{*}{\multicolumn{2}{|c|}{ Model }} & \multicolumn{2}{|c|}{$\begin{array}{l}\text { Unstandardized } \\
\text { Coefficients }\end{array}$} & \multirow{2}{*}{$\begin{array}{c}\begin{array}{c}\text { Standardized } \\
\text { Coefficients }\end{array} \\
\text { Beta }\end{array}$} & \multirow[b]{2}{*}{1} & \multirow[b]{2}{*}{ Sig. } \\
\hline & & B & $\begin{array}{c}\text { Std. } \\
\text { Error }\end{array}$ & & & \\
\hline \multirow[t]{3}{*}{1} & (Constant) & 1.301 & 3,009 & & ,432 & ,667 \\
\hline & $\begin{array}{l}\text { Kualitas } \\
\text { Produk }\end{array}$ & .525 & .087 &, 519 & 6,019 & , 000 \\
\hline & $\begin{array}{l}\text { Kualitas } \\
\text { Pelayanan } \\
\end{array}$ & , 473 & .098 & ,417 & 4,841 & , \\
\hline
\end{tabular}

a. Dependent Variable: Kepuasan pelanggan

Hasil uji parsial, pengaruh kualitas produk terhadap kepuasan pelanggan diperoleh nilai $t_{\text {hitung }} 6,019>t_{\text {tabel }} 1,991$ dengan signifikan $0,000<0,050$ maka Ho ditolak dan $\mathrm{Ha}$ diterima menandakan bahwa terdapat pengaruh positif dan signifikan antara kualitas produk terhadap kepuasan pelanggan.

Pengaruh kualitas pelayanan terhadap kepuasan pelanggan diperoleh nilai thitung 4,841 > tabel 1,991 dengan signifikan 0,000 < 0,050 maka Ho ditolak dan $\mathrm{Ha}$ diterima menandakan bahwa terdapat pengaruh positif dan signifikan antara kualitas pelayanan terhadap kepuasan pelanggan.

\section{Hasil Uji Simultan (uji F)}

Tabel 1o. Uji F hitung Simultan ANOVAa

\begin{tabular}{|l|c|c|c|c|c|c|}
\hline \multicolumn{2}{|c|}{ Model } & $\begin{array}{c}\text { Sum of } \\
\text { Squares }\end{array}$ & Df & $\begin{array}{c}\text { Mean } \\
\text { Square }\end{array}$ & F & Sig. \\
\hline \multirow{4}{*}{1} & $\begin{array}{c}\text { Regres- } \\
\text { sion }\end{array}$ & 2719,560 & 2 & 1359,780 & 140,656 & ,000 $^{\mathrm{b}}$ \\
\cline { 2 - 7 } & Residual & 744,390 & 77 & 9,667 & & \\
\cline { 2 - 7 } & Total & 3463,950 & 79 & & & \\
\hline
\end{tabular}

a. Dependent Variable: Kepuasan Pelanggan

b. Predictors: (Constant), Kualitas Pelayanan, Kualitas Produk

Sumber: Hasil Olahan Data SPSS 23 (2020)

Hasil uji pengaruh kualitas pelayanan dan kualitas produk terhadap kepuasan pelanggan diperoleh nilai $F_{\text {hitung }}$ 140,656 > $\mathrm{F}_{\text {tabel }}$ 3,12 dengan siginifikan o,ooo < 0,05 dengan demikian Ho ditolak dan Ha diterima, artinya secara simultan terdapat pengaruh yang positif antara kualitas produk dan kualitas pelayanan terhadap kepuasan pelanggan.

\section{Pembahasan}

Secara parsial kualitas produk berpengaruh positif dan signifikan terhadap kepuasan pelanggan dengan nilai $t_{\text {hitung }} 6,019>t_{\text {tabel }}$ 1,991 dengan signifikan $0,000<0,050$.

Kualitas pelayanan secara parsial berpengaruh positif dan signifikan terhadap kepuasan pelanggan dengan nilai $t_{\text {hitung 4,841 }}>t_{\text {tabel }}$ 1,991 dengan signifikan $0,000<0,050$.

Kualitas pelayanan dan kualitas produk secara simultan berpengaruh terhadap kepuasan pelanggan diperoleh nilai $F_{\text {hitung140,656 }}>F_{\text {tabel }}$ 3,12 dengan siginifikan $0,000<0,05$.

\section{SIMPULAN}

Hasil dari penelitian ini antara lain:

Secara parsial kualitas produk berpengaruh signifikan terhadap kepuasan pelanggan Rich Perfumery ITC Kuningan.

Kualitas pelayanan secara parsial berpengaruh positif dan signifikan terhadap kepuasan pelanggan Rich Perfumery ITC Kuningan.

Kualitas pelayanan dan kualitas produk secara simultan berpengaruh terhadap kepuasan pelanggan Rich Perfumery ITC Kuningan.

Diperlukan penelitian lanjutan yangdapat mengunkapkan variabel lain yang berpengaruh terhadap kepuasan pelanggan Rich Perfumery ITC Kuningan seperti variabel harga dan promosi.

\section{DAFTAR PUSTAKA}

Abda, N. (2018). Pengaruh Kualitas Produk, Harga, Promosi, dan 
Distribusi terhadap Minat Beli Konsumen Toko Vizcake Pekanbaru. JOM FISIP.5(2), 1-15.

Abdul. S. (2015). Analisis Kebijakan. Jakarta: Bumi Aksara.

Algifari. (2015). Analisis Regresi untuk Bisnis dan Ekonomi. Yogyakarta: BPFE.

Alma, Buchori. (2016).Manajemen Pemasaran \& Pemasaran Jasa, Bandung: CV.Alfabeta.

Amstrong, G \&Kotler, P.(2017). DasardasarPemasaran . Jilid 1, Alih Bahasa Alexander Sindorodan Benyamin Molan. Jakarta: Prenhalindo.

Amstrong,Gary.(2008).Prinsip-

PrinsipPemasaran. Jilid 1. Edisi Kesembilan. Jakarta : PT. Indeks Gramedia.

Arikunto,S. (2013). Manajemen Pemasaran. Bandung: Alfabeta.

Arikunto. S. (2014). Prosedur Penelitian Suatu Pendekatan Praktek. Jakarta: Rineka Cipta.

Assauri, S . (2013).Manajemen Produksi dan Operasi. Edisi Revisi. Jakarta : Lembaga Penerbit Fakultas Ekonomi Universitas Indonesia.

Assauri,S.(2015).ManajemenPemasaranD asar dan KonsepStrategi. Jakarta : PT. GrafindoPersada.

Dharmmesta, B. S.(2014). Manajemen Pemasaran.Yogyakarta : BPFE.

Ghozali, I. (2017). Aplikasi Analisis Multivariate Dengan Program SPSS.Edisi Kelima. Semarang: Badan Penerbit Undip.

Kosasih, A. \& Liu,F. (2018). Analisa Pengaruh Kualitas Produk, Brand Image, dan Promosi terhadap Minat Beli Pelanggan pada Populer Bakery. Jurnal Manajemen Perhotelan, 3(1), 380-394.

Kotler, P. dan Keller, K.L. (2012). Manajemen Pemasaran . Jilid 2.
Edisi DuaBelas. Alih Bahasa: Bob Sabran.Jakarta: PT. Indeks.

Kotler, P. dan Amstrong.G. (2016). PrinsipPrinsip Pemasaran. Jilid 1. Edisi 13. Jakarta :Erlangga.

Lupiyoadi, R. (2014). Manajemen Pemasaran Jasa.Edisi 3.Jakarta: Salemba Empat.

Purba, R. (2012). Measuring Consumer Perceptions Through Factor Analysis. The Asian.

Ratnasari dan Aksa. (2016). Manajemen Pemasaran Jasa. Jakarta: Gramedia. Rizan, M.\& Andika,F. (2011). Pengaruh Kualitas Produk dan Kualitas Pelayanan terhadap Kepuasan Pelangan (Survei Pelanggan Suzuki, Dealer Fatmawati, Jakarta Selatan). Jurnal Riset Manajemen Sains Indonesia (JRMSI). 2(1). 130-150.

Sasangka, I. (2018). Pengaruh Kualitas Pelayanan terhadap Volume Penjualan pada Mini Market Minimart'9o Bandung.Jurnal Ilmiah Manajemen Ekonomi dan Akuntansi, 2(1), 129-154.

Santoso. S.(2015). Menguasai Statistik Multivariat. Jakarta: PT Elex Media Komputindo.

Schiffman dan Kanuk. (2015). Perilaku konsumen. Edisi Tujuh. Jakarta: Indeks.

Sudjana. (2014). Metode Statistika. Bandung: Tarsido.

Sugiyono. (2017). Metode Penelitian Administrasi Dilengkapi dengan Metode $R \& D$.Bandung: Alfabeta.

Supardi. (2013). Aplikasi Statistika dalam Penelitian Konsep Statistika yang Lebih Komprehensif.Jakarta : Change Publication.

Sunyoto,D. (2015). Analisis Data Ekonomi Dengan Menggunakan SPSS. CetakanI. Jakarta: Penerbit PT. Indeks.

Tjiptono. F. Dan Chandra, G. (2016). Service, Quality \&Satisfaction. 
Yogyakarta : Andi.

Tjiptono. F.(2014). Pemasaran Jasa.

Yogyakarta: Andi.

Tjiptono, F. (2019). Strategi Pemasaran.

Yogyakarta: Penerbit CV Andi Offset.

Walker, D. (2012). Manajemen Pemasaran

Suatu Pengantar. Jakarta: Selemba Empat.

Wibisono,D.(2006). Manajemen Kinerja :

Konsep, Desain, dan Tekhnik

Meningkatkan Daya Saing

Perusahaan. Jakarta : Erlangga. 